\title{
Назар ЗАТОРСЬКИЙ
}

кандидат історичних наук,

докторант богослов'я,

Фрібурзький університет

(Фрібур, Швейцарія), nazar.zatorsky@unifr.ch

ORCID: https://orcid.org/oooo-ooo2-II8I-O2O7

\section{Висвячення митрополита Спиридона в контексті «Послання Мисаїла» 1476 р.}

DOI: https://doi.org/10.15407/uhj2021.04.031

УДК: 94(477)«XV»

\begin{abstract}
Анотація. Мета дослідження - розглянути висвяту у Царгороді у середині 1470-х рр. ченця Спиридона на київського митрополита у ситуації, яка склалася в Київській митрополії після Флорентійської унії 1439 р., із залученням свідчень «Послання Мисаїла» 1476 р. про конфесійні настрої й акції русько-литовської церковної і світської еліти. Методологія. Застосовано історіографічний та джерельний аналіз для виявлення нових можливих прочитань біографічних даних про Спиридона. Наукова новизна. Запропоновано нове тлумачення місії Спиридона в Константинополі й, відповідно, осіб, які за нею стояли. Також скориговано датування втечі / звільнення його з ув'язнення в Литві. Висновки. Підсумовуючи наявні джерельні та літописні свідчення, зауважено про необгрунтованість датування поділу Київської митрополії 1448-м чи 1458-м роками. Дії всіх зацікавлених осіб указують на те, що навіть наприкінці 1460-х рр. вони мислили іï неподільною і прагнули контролювати всю іï територію. При цьому дії польсько-литовського монарха Казимира IV щодо митрополита Григорія Болгариновича свідчать про намагання усталити новий modus vivendi для підвладних йому русинів грецької віри, передбачаючи подвійну юрисдикційну підлеглість як Риму, так і Константинополю. Вибір Мисаїла на митрополичу кафедру на початку 1473 р. було зроблено насамперед з огляду на перспективність його визнання на контрольованих Москвою територіях. Відповідні уривки «Послання Мисаїла» 1476 р. свідчать про продовження політики подвійного співпричастя та ії підтримку руською церковною і світською елітою. Під цим оглядом стає очевидною не лише причина посольства Спиридона до Царгорода, а й значення літописних звісток про вдачу посланця та здобуття митрополичого сану підкупом.
\end{abstract}

Ключові слова: Спиридон Сатана, Мисаїл, «Послання Мисаїла», Флорентійська унія, Київська митрополія.

У постаті митрополита Спиридона, як свого часу цілком слушно відзначив В.Ульяновський, відображається тогочасна епоха - період настільки великих церковних змін і зсувів, що їх доречно назвати тектонічними. Серед головних подій насамперед слід згадати Ферраро-Флорентійський собор і підписану I439 р. унію між Східною й Західною церквами. Потім було захоплення турками в I453 p. Константинополя осідку матірної для Київської митрополії церкви. Довершує перелік переломних подій у житті згаданої митрополії XV ст. вихід на завершальний етап процесу ії поділу на Московську та Київську. Саме на тлі цих епохальних явищ і з'являється на історичній арені постать Спиридона з прізвиськом Сатана. Звісно, такі величезні зрушення

1 Див.: Ульяновський В. Митрополит Київський Спиридон: Образ крізь епоху, епоха крізь образ. - К., 2004. 
ані тоді, ані сьогодні не мали й не мають однозначної оцінки і тлумачення. Тож на сприйняття особи цього ієрарха впливали в ті часи та впливають досі не лише його бурхлива епоха, а й способи ії рецепції та розуміння впродовж віків.

У цій статті звернемо увагу на деякі неясні аспекти біографії церковного діяча, що їх через сильний вплив попередньої історіографічної традиції дослідники або взагалі не помічали, або трактували досить однобоко. Ідеться насамперед про питання його висвячення, особливо з огляду на вибраного вже на той момент на київський митрополичий престол Мисаїла та намагання останнього дістати затвердження в Римі, засвідчені в розлогому листі понтифіку від 1476 р. ${ }^{2}$ Саме «Послання Мисаїла до папи Сикста IV» може дати ключ до розуміння подій, що супроводжували подорож Спиридона в Константинополь і висвячення його там на київського митрополита, адже це автентичний церковно-історичний документ доби, в якому події та настрої головних дійових осіб описані ними самими.

Щоб запропонувати нове бачення згаданих аспектів, слід нагадати історичний контекст, звернувши увагу на деякі моменти, які досі залишалися поза увагою істориків. На перший погляд видається, що Флорентійська унія провела демаркаційну лінію по території Київської митрополії, відділивши підлеглі їй єпархії на теренах Польсько-Литовської держави від єпархій на територіях Північної Русі, які перебували під впливом Великого князівства Московського. Для цього доленосного феномену І.Скочиляс і А.Гіль запропонували термін «великий поділ»³.

Однак при детальнішому розгляді документів і подій стає очевидним, що такий погляд на тогочасні реалії $є$ проекцією наших знань про подальший розвиток ситуації та не відповідає інтенціям і сприйняттю тих-таки історичних обставин головними дійовими особами й центрами впливу. Так, каталізатором цього поділу запропоновано вважати вибір на київський митрополичий престол I448 р. без згоди та затвердження з боку константинопольського патріарха ставленика московського князя рязанського єпископа Йони Одноушева ${ }^{4}$, попри те, що живим іще був чинний і визнаваний доти митрополит Ісидор, який, однак, із I443 р. перебував поза межами своєї митрополії5. Проте ця подія не була безпрецедентною в історії київського митрополичого осідку. 3 огляду на постійну боротьбу за спадок Русі місцеві єпископи на бажання свого монарха постійно обирали власного предстоятеля, на противагу обраному конкуруючою стороною, і така практика була радше правилом, ніж винятком уже понад сто років до вибору Йони.

Першою ластівкою тут, напевно, слід уважати виокремлення в гзоз р. з Київської митрополії осібної Галицької та поставлення для неї очільника з юрисдикцією над єпархіями на території Руського королівства ${ }^{6}$, спричинене перенесенням I299 р.

\footnotetext{
2 «Послання Мисаїла» під назвою «Поселство до папежа рымского Сикста д от духовенства и от княжат и панов

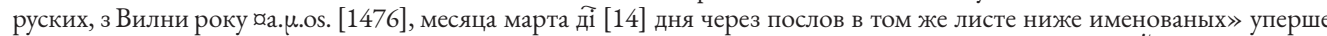
видав 1605 р. унійний митрополит Іпатій Потій за списком, знайденим у церкві міста Крева. Його публікація, здійснена у ситуації полеміки та у відповідних цілях, була сприйнята опонентами з недовірою. Лише у другій половині XIX ст. православні дослідники почали визнавати грамоту Мисаїла автентичним документом. Остаточну крапку тут поставило відкриття наприкінці XX ст. двох списків першої половини XVI ст. Критичне видання послання з урахуванням нововідкритих списків і компіляцій на його основі було здійснене щойно 2018 р., відтак наступного року побачило світ виправлене видання (див.: Заторський о. Н. «Послання Мисаїла до папи Сикста IV» 1476 року: реконструкція архетипу. - 2-ге, випр. й доп. вид. - Л., 2019 (серія «Київське християнство», т.XV)).

${ }_{3}$ Див.: Gil A., Skoczylas I. Przed wielkim podziałem: prawosławna metropolia kijowska do 1458 roku. - Lublin; Lwów, 2013. ${ }^{4}$ Gil A., Skoczylas I. Kościoły Wschodnie w państwie polsko-litewskim w procesie przemian i adaptacji: Metropolia Kijowska w latach 1458-1795. - Lublin; Lwów, 2014. - S.83 («Fakt mianowania metropolitą całej Rusi Jonasza (Jon), władyki riazańskiego, wywołał falę wydarzeń prowadzących do rozbicia Cerkwi na ziemiach ruskich»).

5 Лужнииький Г. Українська церква між Сходом і Заходом. - Филаделфія, 1954. - С.188.

6 Див.: Скочиляс I. Галицька митрополія XIV - першої половини XV століть: особливості еклезіального, правового та суспільного статусу // Княжа доба: історія і культура. - Вип.4. - Л., 2011. - С.252-259.
} 
митрополитом Максимом свого осідку з Києва на північ: спершу до Владимирана-Клязьмі7, а за його наступника Петра в гз2о-х рр. - до Москви ${ }^{8}$. Із тієї ж причини тоді ж, на початку XIV ст., почали вимагати в Константинополі утворення окремої митрополії для підлеглих їм територій і великі князі литовські, тож у І315-1317 рр. було засновано Литовську з центром у Новгородку ${ }^{9}$. Однак назагал патріархія вельми неохоче йшла на поділ Київської митрополії, тож як Галицька, так і Литовська то скасовувалися, то знову відновлювалися внаслідок тиску відповідних володарів ${ }^{\text {го }}$. Тому з часом тактика польсько-литовських монархів щодо руської церкви змінилася: замість постійної боротьби за існування окремої митрополії в їхніх володіннях їм було простіше поставити свого претендента на митрополита київського ${ }^{\text {I. }}$

Упродовж цілого XIV та початку XV ст. простежуємо дві головні тенденції в Київській митрополії, перша з яких полягала в поставленні альтернативних очільників: для північних теренів, що перебували під впливом Москви, з осідком у Владимирі-на-Клязьмі, а відтак у Москві, та для південно-західних земель у володіннях Руського королівства (згодом Польщі) й Великого князівства Литовського з центром у Києві, Вільні чи Новгородку. При цьому спостерігаємо й іншу, не менш важливу тенденцію: намагання цих паралельних ієрархів поширити свою владу на всю територію митрополії, домігшись визнання від конкуруючої сторони ${ }^{12}$. Головним засобом у цьому протистоянні було висвячення чи благословення з боку константинопольського патріарха, яке, проте, не гарантувало такого визнання, а лише давало перевагу в боротьбі за нього, остаточне ж слово залишалося за місцевим монархом ${ }^{13}$.

Як свідчить історія Київської митрополії XIV-XV ст., ані самовільне обрання Йони (попри наявність чинного митрополита Ісидора), ані відсутність для Йони патріаршого благословення не може служити аргументом на користь того, що в 1448 р. відбулась якась безпрецедентна для митрополії подія. Більше того, великий князь московський Василій II Темний таки добився визнання митрополичих прав Йони також на теренах Польсько-Литовської держави: король польський і водночас великий князь литовський Казимир IV Ягеллончик у I45I р. підтвердив їх відповідною грамотою ${ }^{14}$, яка, отже, відновила єдність Київської митрополії під одним предстоятелем на всіх іï дотеперішніх теренах. Тож Йона Одноушев став, фактично, останнім митрополитом, влада котрого впродовж семи років поширювалася на всю Київську митрополію.

Виглядає спокусливим обрати моментом поділу Київської митрополії 1458-й рік, коли папа римський Пій II, продовжуючи починання свого попередника

\footnotetext{
Грушевський М. Історія України-Руси. - Т.3. - К., 1993. - С.269.

8 Там само.

9 Див.: Цукерман К. Із ранньої історії Литовської митрополії // Ruthenica. - T.XIV. - К., 2017. - С.187.

${ }^{10}$ Див.: Грушевський М. Історія України-Руси. - Т.5. - К., 1994. - С.385-404; Лужнииъкий Г. Українська церква між Сходом і Заходом. - С.151-153.

${ }^{11}$ Уперше це сталося, як виглядає, у 1352-1353 рр., коли на противагу до поставленого в Константинополі київського митрополита Теогноста з резиденцією в Москві, у Києві митрополичий престол посів поставлений болгарським патріархом Теодорит, якому підпорядковувалися південно-західні єпархії (див.: Грушевський М. Історія України-Руси. T.5. - C.386-389).

${ }_{12}$ Так, попри наявність у Москві митрополита київського Олексія (помер 1378 р.), для південних земель 1375 р. був поставлений митрополитом київським Кипріан, якому вдалося добитися ліквідації Галицької митрополії, а з часом поширити свою владу й на північноруські єпархії (див.: Там само. - С.393-397).

${ }_{13}$ Це добре простежується на прикладі митрополита Кипріана. Так само було, зрештою, і пізніше, коли, наприклад, попри існування поставленого в Константинополі митрополита київського Фотія, великий князь литовський Вітовт спонукав єпископів підлеглих йому земель обрати в 1415 р. паралельного митрополита Григорія Цамблака, який керував своєю частиною митрополії без будь-якого визнання з боку патріарха в Константинополі, ба навіть усупереч його волі, до 1420 р. (див.: Там само. - С.399-403).

${ }_{14}$ Див.: Русский феодальный архив XIV - первой трети XVI вв. / Сост. А.Плигузов. - Москва, 2008. - №29. - С.151152.
} 
Калліста III's, поділив ії територію на Верхню (Московську) й Нижню (Київську) $)^{16}$, призначивши митрополитом останньої учня Ісидора та його довголітнього супутника Григорія Болгариновича ${ }^{17}$. Утім більшість істориків, які посилаються на цей поділ, цілком ігнорують факт зміни політики Пія у цьому питанні, адже вже за кілька місяців той самий папа підпорядкував Григорієві всю Київську митрополію ${ }^{18}$, вимагаючи від короля та великого князя Казимира IV подбати про забезпечення прав Григорія й ужити заходів для відсторонення самозванця Йони ${ }^{19}$. Крім документів понтифіка про це свідчать також листи до Казимира від обох грецьких вигнанців, котрі перебували в Римі та були архітекторами римської політики щодо Київської митрополії - колишнього вже київського митрополита Ісидора та константинопольського патріарха у вигнанні Григорія Мамми, який у міжчассі й висвятив Григорія на митрополита ${ }^{20}$. Слід зауважити, що ця зміна політики відбулася ще до виїзду нововисвяченого предстоятеля Київської митрополії з Рима ${ }^{21}$, тобто до своєї пастви він прибув уже як митрополит усієї Русі.

3 огляду на це польсько-литовський володар Казимир IV після прибуття в його землі Григорія Болгариновича систематично вживав заходів із метою добитися визнання останнього митрополитом також у Москві. Для цього вже у серпні 1460 p. ${ }^{22}$ до тамтешнього правителя було споряджено відповідне посольство, а коли воно не досягло успіху, Казимир Ягеллончик вирішив домогтися спершу благословення від патріарха в Константинополі, яке мало стати вагомим аргументом на користь митрополичих прав Григорія. Коли ж Симеон Трапезундський у 465 р. відмовив, польсько-литовський державець вислав повторне посольство з такою ж місією до його наступника, патріарха Діонісія, яке I467 р. поставленої мети таки добилося. Тож уже навесні I468 р. до Москви вирушило ще одне посольство від Казимира IV²3, яке мало в руках солідний резон у вигляді патріаршої грамоти з підтвердженням митрополичих

\footnotetext{
${ }^{15}$ Перші кроки у цьому напрямі здійснив іще папа Калліст III, а Пій II довершив цю справу (див.: Halecki O. From Florence to Brest (1439-1596). - Rome; New York, 1958. - P.83-88).

${ }^{16}$ Б.Гудзяк зауважує, що «декрет папи Пія окреслив нові юрисдикційні межі Київської митрополії і на кінець XV cт. їх явно чи неявно визнавали всі зацікавлені сторони» (див.: Гудзяк Б. Криза і реформа: Київська митрополія, Царгородський патріархат і генеза Берестейської унії. - Л., 2000. - С.65). Проте нові юрисдикційні межі Київської митрополії насправді визначалися не стільки декретом папи Пія II, скільки фактичними кордонами між ПольськоЛитовською державою та північними теренами, які знаходилися під впливом Москви, а папські булли лише відтворили наявні на момент їх видання кордони. Яскраво ілюструє цю закономірність ситуація навколо Смоленської єпархії: після переходу в 1514 р. Смоленська під владу Москви вона автоматично опинилася під владою московського митрополита, хоча за декретом Пія II належала до Нижньої (власне Київської) митрополії (пор.: Documenta Pontificum Romanorum historiam Ucrainae illustrantia (1075-1953) / [coll. Welykyj A. G.] // Analecta OSBM. - Series II. - Sectio III. - Vol. I. Romae, 1953. - №82. - Р.146). Щодо термінів «Верхня» та «Нижня» Русь див.: Русина О. Політико-конфесійні орієнтири православних канцеляристів рубежу XV-XVI ст. // Український історичний журнал. - 2017. - №5. - С.14. ${ }_{17}^{17}$ Documenta Pontificum Romanorum historiam Ucrainae illustrantia... - P.145-147.

${ }_{18}$ Так, у папських документах осені 1458 р. постійно наголошувалося, що від Московської та Верхньої Русі відділяється Київська руська церква, територію якої окреслено як «Нижню Литовську та всієї нижньої Русі», указуючи, що саме ця частина підпорядкована Григорієві, називаючи його митрополитом «Київським Литовським і всієї Нижньої Русі» та перелічуючи всі 9 підлеглих йому єпархій, які знаходилися в межах Польсько-Литовської держави (пор.: Documenta Pontificum Romanorum historiam Ucrainae illustrantia... - №82-86. - P.145-151). Проте вже в документах зими $1458-$ 1459 рр. йшлося про підпорядкування «церкви Київської та Русі» (без зазначення окремих їі частин) Григорієві, щодо якого тепер ужито титул «митрополит Київський та всієї Русі» (пор.: Documenta Pontificum Romanorum historiam Ucrainae illustrantia... - №91, 93. - P.155, 157).

19 Пор.: Documenta Pontificum Romanorum historiam Ucrainae illustrantia... - №91. - P.155-156.

${ }^{20}$ Ваврик о. М. Флорентійські унійні традиції в київській митрополії 1450-1460рp. // Analecta OSBM 4 (10), (3-4) (1963). - P.348-349.

${ }^{21}$ Григорія представлено як «Archiepiscopum Chiennensem et totius Russie» у супровідній грамоті для нього від папи Пія II, датованій 17 січня 1459 р. (пор.: Documenta Pontificum Romanorum historiam Ucrainae illustrantia... - №93. P.156-157).

${ }_{22}$ Синицъна Н.В. Третий Рим: Истоки и эвилюция русской средневековой концепции. - Москва, 1998. - С.92.

${ }^{23}$ Там же. - C.112.
} 
прав Григорія на всю територію Київської митрополії та відкиненням Йони і його наступників як самозванців ${ }^{24}$. Згадана грамота Діонісія важлива й тим, що засвідчує позицію Константинополя в питанні поділу митрополії. I позиція ця однозначна: уся вона у своїх давніх межах повинна підлягати Григорієві ${ }^{25}$.

Не вважали Київську митрополію поділеною також у Москві, де як світська, так і церковна влади вимагали не лише від «своїх», але й від єпископів у межах ПольськоЛитовської держави - не приймати Григорія та наполягали на правах митрополита Йони на всю територію митрополії, включно з південними єпархіями ${ }^{26}$.

Як бачимо, і папа Пій II, і унійний константинопольський патріарх у Римі, i константинопольський патріарх у Стамбулі, і великий князь московський ${ }^{27}$, і польсько-литовський монарх намагалися поширити владу свого митрополита на всю територію Київської митрополії ${ }^{28}$. Тому вважати 1458 -й рік датою ії поділу цілком хибно, адже всі зацікавлені сторони мислили ії в давніх межах і прагнули досягти контролю над усіма ії єпархіями, а не лише над Верхньою чи Нижньою частинами. Тож поширений серед багатьох дослідників поділ на митрополитів литовських (київських) і московських ${ }^{29}$ не відповідає ані реаліям I450-I470-х рр., ані самоідентифікації

${ }_{24}$ Див.: Щапов Я.Н. Восточнославянские и южнославянские рукописные книги в собраниях Польской Народной Республики. - Ч.2. - Москва, 1976. - С.145-147. Усупереч тексту грамоти, російські історики, навіть ті, які намагаються переосмислити міфи, пов'язані з московським церковним розколом, досі повторюють тезу, мовляв, із відповіді патріарха випливає, що митрополит Григорій звернувся у Царгород із покаянним листом, а звернення це свідчить про відхід як Григорія, так і Казимира IV (без санкції котрого таке звернення було 6 неможливим) від унії (пор.: Лурье В.М. Русское православие между Киевом и Москвой. - Москва, 2009. - С.79-80). Ось чому вибір Мисаїла та обидва звернення останнього до папи були потрактовані як зміна вектора (тобто спершу прийняття уніата Григорія, тоді «тактична поступка» у вигляді пошуку благословення патріарха константинопольського, тоді знову повернення до проунійної позиції) (пор.: Там же. - С.88-89). Проте жодних подібних мотивів у грамоті патріарха Діонісія 1467 р. не прочитується, а тому говорити про зміну вектора немає жодних підстав. Радше навпаки: лист Мисаїла засвідчує тяглість церковної політики Казимира IV, котрий намагався утримати зв'язок як із Римом, так і $з$ Константинополем та поширити владу свого митрополита на всю територію Київської митрополії.

25 «Про тож годность (/годно есть), только бы тот одинъ былъ митрополитъ истінный (/и) правый на всей руской земли подлугъ старого обычая и звычая руского. Не подобно бо естъ, абы старый обычай и звычай изламанъ былъ старый. а ест тотъ митрополит истінно Киевскіи и всея руси кир Грігорий чоловекъ на велеумны нароженъ, и вскормленъ, и наученъ во цариграде великими добротами и духовными щедротами освященъ. а што вделали (/дђлали) на Москве, ажъ бы того перестали делати, как же указуетъ и приказуетъ святая головная великая церква соборная, бо то ест против правилъ и противъ закону божіего; елико именовали на Москве от ионы и до сихъ часов митрополитов, тых всих великая зборная наша святая церковъ не имаетъ, а ні дръжитъ, а ні именуетъ за митрополитовъ» (див.: Щапов Я.Н. Восточнославянские и южнославянские рукописные книги... - С.146).

${ }^{26}$ Синицына Н.В. Третий Рим... - С.90-108.

27 Переконливі аргументи щодо питання самоідентифікації наступників митрополита Йони навів В.Лурьє: «На основі наявних документальних даних мені видається найбільш розумним уважати, що титул “митрополита московського та всієї Русі” ввійшов у вжиток лише тоді, коли великокнязівська влада остаточно відмовилася від думки про об’єднання митрополії. Можливо, це відбулося тільки у XVI ст. Що ж до саме митрополита Феодосія, то є непрямий, утім вагомий довід на користь того, що його теж зводили на престол “київський і всієї Русі”. Збереглася соборна грамота тверському єпископові Геннадієві з повідомленням про кончину митрополита Йони та із запрошенням до Москви на настоловання обраного самим Йоною наступника (РІБ, 1908, стлб. 685-688). Там про обрання Феодосія сказано такими словами: “И господин наш и отец Иона, митрополит Киевский и всея Руси, разсудив [...] избрал и благословил на тот превеликий степень святительства”. Указівний займенник “тот” уповні однозначно вказує на титул митрополита київського, і це в тексті, написаному за декілька тижнів до настоловання Феодосія» (див.: Лурье В.M. Русское православие между Киевом и Москвой. - С.75-76). Це спостереження В.Лурьє дозволяє дещо скоригувати висновки А.Плігузова (див.: Плигузов А.И. О титуле «митрополит киевский и всея Руси» // Русский феодальный архив XIV первой трети XVI вв. - Ч.5. - Москва, 1992. - С.1034-1042).

${ }^{28}$ Що цілком слушно відзначив о. П.Біланюк, зауважуючи, що поділ митрополії папою Каллістом III «не поклав край політичному маневруванню всіх зацікавлених сторін і спробам отримати контроль над обома частинами митрополії (див.: Bilaniuk P.B.T. The Five-Hundredth Anniversary of the Letter of Misael, Metropolitan-Elect of Kiev, to Pope Sixtus IV (1476-1976) // Studies in Eastern Christianity. - Munich; Toronto, 1992. - P.131).

${ }^{29}$ Пор.: Макарий (Булгаков). История русской церкви. - Кн.4-5. - Т.6-9. - Москва, 1994-1996; Синицына Н.В. Третий Рим... - С.113. Натомість П.Дмитрієва в біографії митрополита Спиридона цілком слушно відзначила, що «у 70-х pp. XV ст. йшла запекла боротьба за митрополію “всея Русі” між московським і литовським митрополитами» (див.: Дмитриева Р.П. Спиридон-Савва, киевский митрополит // Словарь книжников и книжности Древней Руси. - Вып.2 (Вторая пол. XIV - XVI в.). - Ч.2: Л-Я. - Ленинград, 1989. - С.408). 
безпосередніх учасників подій. Поділ Київської митрополії був не одномоментним актом, а складним процесом, що супроводжував боротьбу за спадщину Київської Русі - із великою кількістю учасників, інтересів, різнобіжних тенденцій, що й зумовило його кількасотлітнє тривання ${ }^{30}$.

Лише усвідомивши цю обставину, можемо правильно оцінити вибір наступника спочилого наприкінці 1472 або на початку 1473 р. митрополита Григорія ${ }^{31}$. А вибрано було кандидата, який мав найбільші шанси на визнання також у Москві - смоленського єпископа Мисаїла. Про те, що вибір цей робився саме з прицілом на поширення його влади на всю територію Київської митрополії, а не лише ії литовську частину, свідчать два важливих моменти з його біографії: г) Мисаїла поставив єпископом митрополит Йона Одноушев ${ }^{32}$, тож вибір першого на митрополичий престол свідчив і про визнання другого за правочинного митрополита та святителя, усупереч заявам грамоти патріарха Діонісія від 1467 р.; 2) Мисаїл був добре знаний також світській владі в Москві (від якої, власне, найбільше залежало визнання його митрополичих прав), адже в 1456 р., ще як смоленський єпископ, він приїздив туди з великим почтом і вів переговори з московським князем щодо повернення до Смоленська забраної звідти чудотворної ікони Божої Матері. Щобільше, та місія Мисаїла мала успіх: великий князь із митрополитом Йоною, після врочистих богослужінь, процесії і благословення князя й цілого двору, «відпустили» образ. Таким чином, на момент свого обрання на престол київського митрополита Мисаїл був добре відомий Іванові III Васильовичу, котрому на час приїзду того до Москви по ікону було вже 16 років і він, без сумніву, пам’ятав і гостинне прийняття смоленського єпископа своїм батьком, великим князем московським Василієм II Васильовичем (Темним), і виявлену йому пошану через задоволення висловленого прохання. Тож якщо котрийсь з єпископів Польсько-Литовської держави й міг добитися визнання як митрополит київський на підконтрольних Москві теренах, то лише Мисаїл. Принаймні з того, що нам відомо, його шанси на це були найбільшими і його вибір на митрополита яскраво свідчив про такі устремління Казимира IV та всіх, хто був причетний до Мисаїлового обрання.

Для здобуття такого визнання з боку Москви вельми підходив й історичний момент, адже якраз 5 квітня 1473 р. помер московський митрополит Філіп І. Це сталося буквально за кілька тижнів після вибору Мисаїла (якщо прийняти за момент вибору сейм у Вільні наприкінці лютого I473 р.33) або під час вибору (якщо елекційний собор

\footnotetext{
${ }^{30}$ Важко сказати, коли процес поділу Київської митрополії завершився, це вимагало б окремого дослідження. Наразі можна вказати на надання Московській церкві статусу патріархату в 1589-1593 рр. як на завершальний етап цього процесу. А для розглядуваної нами теми достатньо звернути увагу на те, що в 1470-х рр. Київська митрополія ще сприймалася всіма учасниками подій у своїх давніх межах.

31 Датування смерті митрополита Григорія щойно кінцем 1473 р. пояснюється намаганням В.Ульяновського обгрунтувати первинність «акції Спиридона» та вторинність обрання Мисаїла, яке він, відповідно, датує 1476-м роком (див.: Ульяновський В. Митрополит Київський Спиридон... - С.14). Однак така хронологія, поперше, не оперта на жодні свідчення джерел, які натомість датують смерть Григорія Болгариновича осінню 1472 чи зимою 1473 рр. (пор.: Полное собрание русских летописей (далі - ПСРЛ). - T.4. - IV.V: Новгородские и псковские летописи. - Санкт-Петербург, 1848. - С.246); по-друге, така хронологія подій цілком ігнорує свідчення «Послання Мисаїла» про соборний лист від 1473 р., в якому найвірогідніше йшлося про вибір Мисаїла на митрополита та прохання до папи його затвердити.

32 Збереглася ставлена грамота митрополита Йони для Мисаїла як смоленського єпископа, що постала між 9 лютого 1451 та 31 серпня 1454 р. (див.: Русский феодальный архив XIV - первой трети XVI вв. - Ч.3. - Москва, 1987. - С.600601). Вочевидь Мисаїл користувався в Йони особливою довірою, адже крім ставленої нам відомо ще дві грамоти від цього очільника Київської митрополії до смоленського єпископа - стільки не було надіслано більше до жодного єпископа в Литовсько-Польській державі (див.: Русский феодальный архив XIV - первой трети XVI вв. - Москва, 2008. - №24, 60. - С.137-140, 209-210).

${ }_{33}$ Про виборчий сейм у Вільні «всередині Великого посту» згадує Ян Длугош (див.: Dtugosz J. Dzieje polskie. - T.V. Ks.XII. - Krakow, 1870. - S.545). При цьому хроніст уживає специфічного терміна «śródpoście», що вказує на день, до якого були прив'язані певні народні традиції та який обходили у середу через 20 днів після Попільної середи (яка того
} 
відбувався вже після Пасхи, котра тогоріч припадала на 23 березня). За умови справедливості останнього припущення (хоча сейм як нагода для вибору митрополита виглядає ймовірніше), ця обставина була ще одним вагомим аргументом для вибору смоленського єпископа саме з огляду на перспективу його визнання в Москві (якщо, звісно, інформація про смерть митрополита-конкурента встигла дійти до учасників елекційного собору).

Важливою для визначення дати обрання Мисаїла є згадка в «Посланні Мисаїла» про лист до папи, доручений легатові Антоніо Бонумбре ${ }^{34}$ (що саме повертався 3 Московіі), яким, судячи зі соборного характеру цього документа, і повідомлялося Сикстові IV про вибір нового митрополита та прохалося благословити його 35 . На користь саме такого тлумачення змісту втраченого листа I473 р. свідчать і певні спостереження щодо змісту «Послання Мисаїла» I476 р. По-перше, у листі I476 р. цілком відсутнє прохання благословити Мисаїла на митрополичий престол Києва. По-друге, попри твердження Б.Флорі ${ }^{36}$, у грамоті Мисаїла 1476 р., на відміну від Берестейських артикулів 1595 р., з якими дослідник ії порівнює, не тільки не висувалися умови прийняття Флорентійської унії, але відсутні навіть натяки на переговори щодо неї. Автори послання відштовхувалися від своєї унійності як від доконаного фактуз, у зв'язку з чим скаржилися на переслідування їх і нападки з боку місцевого латинського духівництва ${ }^{38}$. По-третє, натомість укладачі наполегливо благали папу відповісти на їхнє попереднє звернення від 1473 р.39, в якому, отже, і було висловлено прохання, пов’язані з необхідністю благословити новообраного предстоятеля Київської митрополії. Що стосується маршруту Антоніо Бонумбре, то ще на початку квітня 1473 р. він

року припадала на 5 лютого). Тож «śródpoście» в 1473 р. було 26 лютого, коли, відповідно до звістки Я.Длугоша, і відбувався сейм у Вільні.

34 «трохи часу минуло відтоді, як послали до вашої, до всенайсвятішої святості від наших сторін наші святі отці, чесні преосвященні єпископи, а також і пренайясніші великославні князі й вельможні та многочесні благородні пани, й усі благочестиві нарочиті мужі певне послання своєчасно вашим легатом на ім'я Антоній, мужем чеснйм і достойним у святості, якого ваша всенайпресвятіша святість послали до великого князя московського» (див.: Заторсъкий о. Н. «Послання Мисаїла до папи Сикста IV» 1476 року... - C.468-469).

35 Такі ж висновки про вибір Мисаїла митрополитом на початку 1473 р. на підставі аналізу характеристик переданого папі через Антоніо Бонумбре листа зробили й інші дослідники (див.: Флоря Б.Н. Попытка осуществления церковной унии в Великом княжестве Литовском в последней четверти XV - начале XVI в. // Славяне и их соседи. - Вып.7. Москва, 1999. - С.45; Halecki O. From Florence to Brest... - P.100-101). Суперечливою є оцінка подій та змісту листа 1473 р. М.Грушевським: з одного боку, він також приймав, що на соборі весни того року йшлося про вибір Мисаїла, оскільки описував його як «православний собор... - мабуть той, що зібрав ся був для обсади митрополії» (див.: Грушевсъкий М. Історія України-Руси. - Т.5. - С.531). Хоча в тому ж томі дещо раніше історик постулював, що Мисаїла було вибрано за невідомих обставин щойно кілька років по смерті Григорія, себто невдовзі перед укладенням «Послання Мисаїла» 1476 р. (пор.: Там само. - С.409-410).

${ }_{36}$ Пор.: Флоря Б.Н. Исследования по истории церкви: Древнерусское и славянское средневековье. - Москва, 2007. С.253-254.

37 «Задля цього й ми припадаємо звідси до тебе й молимо твоє людинолюбство: о владико, будь милостивим до нас, які живемо далеко в північних краях, у місті ясновельможної руської череди, згідно з устроєм і порядком Східної церкви, дотримуючися святих семи вселенських соборів, разом із ними ж і восьмий Флорентійський схвалюючи, $\mathrm{i}$ всього того, що на них постановлено святими отцями, тримаючись у повноті та міцно у вірі святій, істини пильнуючи, дотримуємо» (див.: Заторський о. Н. «Послання Мисаїла до папи Сикста IV» 1476 року... - С.427-428).

38 «и ж віруємо всій вашій найсвятішій, великорозумній, у розважливості вельми глибокій премудрості, що не ймете віри цим, а також іншим, подібним до цього, речам, якими брешуть на нас, незгідно з істиною, бажаючи розгнівити твоє незлобиве, благе милосердя до нас. Тому й умовляємо та благаємо властиве твоїй вдачі милостиве твоє милосердя: заступайся милостиво і за нас перед Богом, аби спас задля тебе душі наші. [...] Ми-бо всі віруємо й визнаємо, що ти всенайсвятіший пастир і вселенський всеначальніший старійшина для всіх священних отців і верховний праотець православних патріархів, та схиляємо голови наші з усяким послухом зичливим» (див.: Там само. - С.419).

39 «Та не знаємо, що з цим таке, чи донесені були тії писання наші перед ваше святительське всенайпресвятіше лице, чи ні. [...] Повідай нам се, всенайсвятіший отче: з якої причини сталася ця річ із таким загаянням, що не отримали ми бажаної милості від вашої всенайпресвятішої святості? Бо ми віруємо вашій великій премудрості, що з цього не пізнається жодного якогось вашого недбальства щодо нас у цих речах, але на все це нам із любов'ю відпишеш, як милостивий отець наше смирення і жадання миру в усьому сповниш, а не засмутиш відтепер уже більше наших сердець» (див.: Там само. - С.469-470). 
перебував у Вільні, як свідчить його грамота від г квітня того року ${ }^{40}$. А оскільки наступна відома нам грамота легата, датована 22 травня, видана у Старгарді ${ }^{41}$, то 3 огляду на відносно невелику відстань між обома містами, навіть якщо папський посланець вирушив із Вільна щойно наприкінці квітня, у нього було достатньо часу, аби досягти Старгарда ще перед цієї датою. Тому таке пізнє датування вибору Мисаїла на митрополита (після смерті Філіпа I в Москві 5 квітня I473 р.) теж можливе, оскільки й у цьому випадку було достатньо часу, щоби вручити Антоніо Бонумбре листа від собору руських єпископів і князів із проханням папського благословення для новообраного київського митрополита.

При цьому сподіванням Казимира IV домогтися визнання «свого» митрополита Москвою жодним чином не суперечить факт унійності останнього, виразно виявлений у переданому I473р. через апостольського нунція Антоніо Бонумбре соборному проханні до папи затвердити Мисаїла на митрополичому престолі та в повторному нагадуванні про необхідність це зробити посланням від 1476 р. Радше навпаки: ці кроки свідчать про намагання польсько-литовського монарха виробити новий modus vivendi для підлеглих йому русинів грецької віри, моделлю для якого був Григорій Болгаринович. Зі змісту листа I476 р. можна зробити висновок, що для Мисаїла передбачалося не лише затвердження його Римом на київському престолі, а й здобуття, як колись і для Григорія, паралельного визнання з боку патріарха в Константинополі, що мало стати важливим аргументом для Москви та підлеглих їй єпархій. Саме тому в «Посланні Мисаїла» наявні не лише визнання власної унійності й папської влади, а і влади константинопольських патріархів ${ }^{42}$, що видавалося незрозумілим для пізніших дослідників, котрі мислили в постберестейській парадигмі: якщо з Римом, то не з Константинополем. Відповідні пасажі грамоти Мисаїла свідчать про підтримку руською світською та церковною елітою Литви такого курсу свого правителя і продовження намагань об'єднати під владою одного очільника всю Київську митрополію, чому мала сприяти вже сама особа новообраного предстоятеля. Адже, на відміну від його попередника Григорія, котрий був супутником ненависного Москві Ісидора і призначений папою в Римі, Мисаїл був місцевим, висвяченим на єпископа смоленського московським ставлеником Йоною та обраним на митрополію собором місцевого духівництва, князів і шляхти ${ }^{43}$, що мало усунути всі перешкоди до його прийняття в північноруських землях.

Ці вступні зауваги необхідні, щоб мати змогу поглянути на факт висвячення Спиридона на київського митрополита у Царгороді свіжими очима. Отже, нам відомо про дві спроби добитися для Мисаїла як митрополита київського благословення від папи римського: у 1473 р. через легата Антоніо Бонумбре було передано соборне

\footnotetext{
${ }^{40}$ Див.: Kodeks dyplomatyczny katedry i diecezji wileńskiej (1468-1501) = Codex diplomaticus ecclesiae cathedralis necnon dioeceseos Vilnensis (1468-1501) / Wyd. J.Fijałek, W.Semkowicz. - T.1. - Zesz. 2. - Kraków, 1939. - №280. - S.327-328.

${ }^{41}$ Див.: Untergehrer $W$. Die päpstlichen nuntii und legati im Reich (1447-1484): Zu Personal und Organisation des kurialen Gesandtenwesens. - München, 2012. - S.631-632.

${ }_{22}$ «Та в усьому цьому твоєму такому премудрому дбанні й піклуванні про божественних овець, усі ми тут, у краю далекому, словесні овечата того ж стада Христового з кошари Иого святої, Святої Соборної тієї ж Апостольської Церкви, від чотирьох євангелистів, вселенських пресвятіших патріархів грецьких, згідно з уставом їхнього звичаю та через навчання передання їхнього грецького церковного породжені бувши від купелі святої та життєначальної Трійці [омовінням відродження] [i] [оновлення[м]] згори благодаттю Святого Духа. Ті-бо (патріархи) нас добре пасуть в істинному благовір'ї на пасовиськах живоносних, на квітучих горах північної країни» (див.: Заторський 0 . H. «Послання Мисаїла до папи Сикста IV» 1476 року... - С.411-412).

${ }_{33}$ Тому цілком хибною є теза, що Мисаїл був номінований «з наказу короля» Казимира (див.: Ульяновський $B$. Митрополит Київський Спиридон... - С.112, 123). Як показує згадка про лист 1473 р., Мисаїл був не номінований, а саме обраний, i то обраний соборно руською духовною та світською елітою. Зрештою, на хибність тези про можливість одноосібного затвердження митрополита монархом указує і процедура затвердження присланого з Риму попередника Мисаїла - митрополита Григорія, якого затверджено на сеймі 1461 р. (пор.: Halecki O. From Florence to Brest... - P.93).
} 
послання з проханням про це, а в I476 р. надіслано нагадування про необхідність відповісти на попередній запит ${ }^{44}$ із символічною кількістю підписів представників еліти.

Проте нам нічого не відомо про намагання добитися визнання від патріарха у Царгороді, хоча відповідні уривки «Послання Мисаїла» свідчать, що такі кроки на I476 р. якщо ще не були зроблені, то планувалися. Тим більше, хронологічний проміжок між обома посланнями до папи цілком достатній для того, аби в міжчассі домогтися визнання від патріарха. I саме тут доцільно звернути погляд на висвячення в Константинополі Спиридона Сатани на київського митрополита. Дотеперішні дослідники, керуючись логікою постберестейського періоду (якщо з Римом - то не з Константинополем), не звернули уваги на найпростіше та найлогічніше припущення стосовно посольства Спиридона до Константинополя: він їхав туди не як кандидат у митрополити, а як посол, щоб випросити патріарше благословення для вибраного на митрополита Мисаїла. Тому всі намагання відшукати якихось таємних покровителів Спиридона, котрі начебто стояли за його висланням до патріарха як альтернативного кандидата ${ }^{45}$, досі виявлялися марними - адже їх просто не було. Насправді за посольством Спиридона стояли не якісь могутні таємні інтриґани, а ті самі особи, що й за обранням Мисаїла. Просто слід розділяти посольство Спиридона до Константинополя та факт його висвячення там на митрополита.

На користь такого припущення свідчить низка спостережень:

I) Саме монахам не раз доручалася ця місія також у випадку наступних після Мисаїла митрополитів київських. Так, прохання про затвердження Макарія Чорта двадцятьма роками пізніше возили в Константинополь ченці Діонісій і Герасим, про що згадує патріарша благословенна грамота ${ }^{46}$.

2) Висвячення цілком іншої особи, замість тієї, для якої первісно мало прохатися благословення, теж не було безпрецедентним явищем - за сто років до цього саме так замість висланого московським князем, але померлого під час подорожі кандидата на Київську митрополію Михаїла (Мітяя) благословення в Константинополі здобув один з учасників посольства Пімен ${ }^{47}$. Ми не випадково подаємо тут повне церковне ім’я цього кандидата на митрополію - Михаїл, яке є паронімом до імені Мисаїл, що могло викликати відповідні асоціації і сподівання в посланого з такою ж місією, як і Пімен, монаха Спиридона. Особливо спокусливою могла видатися така ідея в тому випадку, якщо посол у часі подорожі чи перебування у Царгороді отримав звістку про важку хворобу та/або близьку смерть Мисаїла, який на момент обрання на митрополію мав поважний вік, адже до того вже понад 20 років був єпископом смоленським.

3) Спиридон, поза всяким сумнівом, був особою вельми амбітною та честолюбною, що визнають навіть його пошановувачі ${ }^{48}$. Тож він цілком міг уважати себе за

\footnotetext{
${ }_{44}$ Тут не має значення, чи отримав адресат ці документи. Судячи з усього - ні (див.: Заторсъкий Н. Посольство до папи Сикста IV з посланням Мисаїла у світлі деяких документів Ватиканського таємного архіву // Міжнародні зв'язки України: наукові пошуки і знахідки. - Вип.26. - К., 2017. - С.11-30). Проте це вже наше апостеріорне знання, якого учасники подій не мали, тому пишучи 1476 р. нову грамоту, виходили з того, що їхнього першого листа було вручено. Це важливо для розуміння логіки їхніх дій.

${ }^{45}$ Розгорнутий аналіз усіх теорій щодо таких таємних покровителів подав В.Ульяновський (див.: Ульяновський $B$. Митрополит Київський Спиридон... - С.50-78).

${ }^{46}$ Див.: Русский феодальный архив XIV - первой трети XVI вв. - Ч.3. - №20. - С.633.

${ }_{47}$ Див.: Chodynicki K. Kościół prawosławny a Rzeczpospolita Polska: zarys historyczny, 1370-1632. - Warszawa, 1934. - S.21-25. Докладно історію Михаїла (Мітяя) див.: Прохоров Г.М. Повесть о Митяе: Русь и Византия в эпоху Куликовской битвы. - Ленинград, 1978.

${ }^{48}$ Це, зокрема, проявилося при написанні ним на засланні у Ферапонтовому монастирі «Житія святих преподобних Зосими та Савватія Соловецьких». Як слушно зауважив В.Ульяновський: «Одразу зазначимо, що особливості агіографічного жанру вимагали самоприниження й непомірної скромності автора. Але Спиридон не дотримується цієі традиційної та добре відомої етикетної форми. Вже на початку він називає Зосиму і Савватія рабами Божими і тут
} 
достойнішого, кращого чи відповіднішого кандидата, ніж Мисаїл. Не останню роль у підігріванні амбіцій Спиридона відігравала його вченість і високі інтелектуальні здібності ${ }^{49}$, які, швидше за все, послужити підставою обрання саме його кандидатури для посольської місії.

4) Будучи послом короля й великого князя Казимира, а також духовної верхівки Київської митрополії, Спиридон, без сумніву, мав на руках відповідні документи, що засвідчували його повноваження.

5) Як посланий із такою важливою місією він мав і достатньо коштів для того, щоб добитися бажаного. Про те, що він прибув у Константинополь зі справді великим фінансовим забезпеченням, свідчить як його довге там перебування ${ }^{50}$, так і те, що він домігся для себе уряду веститора Великої церкви ${ }^{\text {г }}$.

6) Раннє датування В.Ульяновським приїзду Спиридона в Константинополь I474-м роком ${ }^{52}$ цілком збігається у часі з вибором на київський митрополичий престол Мисаїла (не пізніше травня 1473 р.) та опосередковано свідчить на користь висловленого здогаду, що Спиридон був висланий до Константинополя саме для здобуття патріаршого благословення новообраному митрополитові.

7) Припущення про те, що Спиридон скористався наявними в нього ресурсами для отримання висвячення, дає змогу в новому світлі потрактувати слова джерел 3 описом вдачі посланця: говорячи, що він був за «резвость свою прозван Сатаною» ${ }^{53}$, літописці, вочевидь, мали на увазі не так холеричний чи сангвінічний темперамент Спиридона ${ }^{54}$, як саме його хитрість. Адже слово «рђзвый» означає «проворный, ловкий», а для слова «рђзвость» подається переклад «бойкость», беручи за приклад якраз згадку про Спиридона 55 .

8) Отже стає зрозумілою згадка про поставлення Спиридона в Константинополі «по мздъ» ${ }^{6}$ : тут ішлося не про виплату за висвячення (оскільки за це платили всі митрополити), а про незаконність його поставлення, адже він не був передбаченим та обраним кандидатом, а добився свячень винятково завдяки наявним у його розпорядженні засобам.

9) На користь того, що поставлення Спиридона митрополитом не планувалося, свідчить й отримання ним усіх ступенів священства щойно в Константинополі ${ }^{57}$. Якби котрісь дуже впливові та багаті таємні покровителі справді існували (а такі мусили

же іменує себе повною титулатурою, відмовившись від традиційного саме для агіографа раба Божого. Цим Спиридон явно демонструє, що складання ним Житія є честю не для нього, а для засновників Соловецького монастиря» (див.: Ульяновський В. Митрополит Київський Спиридон... - С.26).

49 Тому при розгляді одного з його творів В.Ульяновський пише: «Ця побіжна замітка є характерною рисою інтелектуала-митрополита, котрий часто демонструє свою обізнаність. Цікавим є те, що Спиридон, нічого не сказавши про рішення собору, уточнює місце його проведення, ніби хизуючись своєю обізнаністю. Таке “хизування”, як уже зазначалося, є характерною рисою автора й важливим штрихом до його психологічного портрета. Принаймні, проблема - бути і здаватися, створити враження і виконати щось не задля враження - для нашого героя не вирішувалася однозначно. Враження про його особу все-таки дуже хвилювало Спиридона» (див.: Там само. - С.164).

${ }^{50}$ На переконання В.Ульяновського, Спиридон перебував у Царгороді принаймні кілька років (див.: Там само. - С.1416).

51 Див.: Турилов А.А. Забытое сочинение митрополита Саввы-Спиридона литовского периода его творчества // Славяне и их соседи. - Вып.7. - С.121-122, 127.

52 Див.: Улъяновський В. Митрополит Київський Спиридон... - С.14-16.

${ }_{53}$ ПСРЛ. - Т.6. - Санкт-Петербург, 1853. - С.233; Т.20. - Ч.1. - Санкт-Петербург, 1910. - С.348.

${ }^{54}$ Пор.: Ульяновський В. Митрополит Київський Спиридон... - С.43-44.

55 Див.: Словарь русского языка XI-XVII вв. - Вып.22. - Москва, 1997. - С.136.

${ }_{56}$ Пор.: ПСРЛ. - Т.24. - Петроград, 1921. - С.195.

${ }^{57}$ Натомість зроблені В.Ульяновським висновки, коли він добачає якийсь глибокий богословський зміст за словами Спиридона про отримане в Константинополі «рућположение чстнаго презьвитерств $a$ ї иж о хсъ дьњконьства», $\epsilon$ цілком необгрунтованими (пор.: Улъяновсъкий В. Митрополит Київський Спиридон... - С.16-17). Насправді цей зворот - просто парафраза мирної єктенії, яку співають на численних богослужіннях (як-от вечірня, утреня,

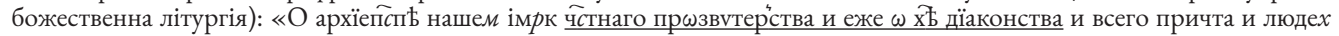


бути, щоб забезпечити фінансовий бік цього заходу) та висилали його до патріарха як альтернативного кандидата до вибраного на митрополита Мисаїла (чи московського ставленика Геронтія), то вони без зайвого ризику могли подбати про висвячення Спиридона в диякони та ієреї (ієромонахи) ще в Київській митрополії, тож патріархові залишалося б лише хіротонізувати його на єпископа й поставити на митрополита. Натомість до Константинополя приїхав простий чернець, без жодних, навіть дияконських, свячень. Про яких багатих і впливових покровителів може бути мова, якщо вони не могли забезпечити своєму кандидатові бодай дияконських та ієрейських висвячень перед висиланням до патріарха?! Коли ж вони навіть таких елементарних та очевидних (якщо Спиридон справді передбачався як альтернативний митрополит) речей не могли досягти, то як тоді збиралися обстоювати його митрополичі права супроти Мисаїла, вибраного соборно всіма руськими єпископами, князями й панами та затвердженого королем і великим князем Казимиром IV, чи ж Геронтія, котрого підтримував московський великий князь і підвладні йому єпископи? Такі міркування роблять припущення про висилання Спиридона до Константинополя в ролі альтернативного кандидата вельми сумнівними. Усе це свідчить радше на користь того, що він прибув з офіційною місією, метою якої було затвердження Мисаїла ${ }^{58}$ у сані митрополита київського, проте скористався своїм становищем і наявними в його розпорядженні документами, коштами й подарунками для того, щоб отримати поставлення на митрополію для себе самого. Ось чому його мусили спершу висвятити на диякона, відтак на священика та лише потім на єпископа - адже він сам не мав жодних свячень і ніхто його на митрополита ставити не планував. I тут не так уже й важливо, коли та з якої причини йому спало на думку скористатися слушною нагодою для власних інтересів.

го) Якби за висвяченням Спиридона справді стояли дуже багаті та впливові покровителі, котрі бажали висунути його на митрополичий престол попри наявність обраного соборно й затвердженого монархом Мисаїла, то в них мала б бути програма утвердження в ролі митрополита першого та усунення другого, а отже задіяти цей план після успішного висвячення їхнього ставленика в Константинополі, чи хоча 6 підняти свій голос на захист законно поставленого патріархом архіпастиря. Проте замість цього ми спостерігаємо цілковите ігнорування факту ув'язнення Спиридона після його приїзду до Польсько-Литовської держави як із боку місцевих світських і церковних еліт ${ }^{59}$, так і сусідів, котрих часом пропонують на роль таких таємних покровителів - великих князів тверського й московського.

II) Сама теза про таємних покровителів Спиридона внутрішньо дуже суперечлива. Адже, з одного боку, іï прихильники представляють цих протекторів такими могутніми, що вони можуть забезпечити свого протеже необхідними фінансами та зв'язками для отримання хіротонії в Константинополі, а з іншого боку - ці патрони виявляються настільки слабкими й незначними, що мусять залишатися в тіні, і то не лише до свячень Спиридона, що було б цілком зрозуміло через конспірацію, а й після, коли вони не тільки могли б дозволити собі виступити як його прибічники, а просто зобов’язані були це зробити, якщо справді мали серйозні наміри висунути Спиридона

гоу помоли». Рук.83 (Служебник). - XVI в. - Л.85 об. (Российская государственная библиотека (Москва). Научноисследовательский отдел рукописей. - Ф.113).

${ }^{58}$ Бо для московських властей, судячи з документів того часу, навіть мови не могло бути про те, щоб звернутися до Царгорода по затвердження для Геронтія (див.: Синищъна Н.В. Третий Рим... - С.108-115).

59 Єдиним аргументом на користь прийняття Спиридона на території Польсько-Литовської держави з боку еліт, на який спромоглися дослідники, є лагідний тон його послання (див.: Макарий (Булгаков). История русской церкви. C.52). Цікаво, а як інакше він міг звертатися, перебуваючи в ув'язненні чи то пак на засланні? Адже він явно був не в тому становищі, щоб говорити з позиції сили. 
як альтернативу до Мисаїла (чи Геронтія). Проте жодні протектори на його підтримку не виступають ані після отримання Спиридоном свячень і повернення в Литву, ані після ув'язнення його Казимиром IV. Із цього випливає, що або Спиридон не мав ніяких покровителів, або ж це були вельми незначні особи, принаймні не з численних представників князівських родів Рюриковичів чи Гедиміновичів. Однак у такому разі стає незрозумілим, звідки в нього взялися необхідні дипломатичні та фінансові засоби, необхідні для досягнення митрополичого сану в Константинополі. Лише відкинення теорії змови щодо Спиридона та прийняття тези про нього як про офіційного посланця до Царгорода задля отримання патріаршого благословення для Мисаїла дозволяє пояснити ці моменти, а також факт його ув'язнення в Литві - адже всупереч завданню отримати благословення для останнього, Спиридон здобув висвячення для себе.

У цьому контексті вельми малоймовірною виглядає теза про київських князів Олельковичів у ролі таємних покровителів Спиридона, позаяк і вони теж не виступили на його підтримку після прибуття того в Литву та ув'язнення ${ }^{60}$. Непереконливим $\epsilon$ припущення про мотивацію Олельковичів як покровителів Спиридона задля піднесення Києва ${ }^{61}$, адже воно не враховує, що якби Спиридона визнав Казимир IV (що, зрештою, мало бути кінцевою метою, якби його справді посилали в ролі альтернативного кандидата), то він перебував би не в Києві, а в одній з офіційних тогочасних резиденцій київських митрополитів - у Вільні чи Новгородку, як перебував там митрополит-елект Мисаїл, котрого в Польсько-Литовській державі визнавали правним очільником Київської митрополії ${ }^{2}$. А теза про плани Олельковичів тримати Спиридона в Києві в ролі невизнаного митрополита ${ }^{63}$ надто неправдоподібна, оскільки наївно було 6 розраховувати, що Казимир дозволив би вільно «гуляти» по своїх землях якомусь зайшлому ієрархові з претензіями на Київську митрополію, і ув’язнення ним Спиридона відразу після прибуття останнього до Литви чудово про це свідчить. При цьому цілковите ігнорування Олельковичами факту ув'язнення Спиридона та підписи князів Михайла Олельковича і його двоюрідного брата Федора Більського під «Посланням Мисаїла» якраз у той час, коли в Київській митрополії дізналися про ставленика Царгорода, найкраще засвідчують підтримку Олельковичами (та їхніми союзниками) саме Мисаїла як митрополита київського ${ }^{64}$ й офіційного курсу польсько-литовського монарха на подвійне співпричастя русинів: як із Римом, так і $з$ Константинополем.

\footnotetext{
${ }_{60}$ Хоча з тексту їхніх підписів у «Посланні Мисаїла» стає очевидним, що нащадки київського князя Володимира Ольґердовича не зреклися своїх претензій на королівський престол Польщі та великокняжий Литви - претензій, що врешті вилилися у «змову князів» 1481 р. Так, Михайло Олелькович підписався як «великославний князь, яснороджений Михайло, брат по плоті пресвітлого короля польського [...] Казимира, [князя] литовського й руського пана». Подібно і його двоюрідний брат князь Більський: «Благовірний князь Теодор із Білої, брат по крові великого князя литовського Андрія» (див.: Заторський о. Н. «Послання Мисаїла до папи Сикста IV» 1476 року... - С.398399).

${ }_{61}$ Див.: Улъяновський В. Митрополит Київський Спиридон... - С.81, 86 та ін.

${ }^{62}$ Про перебування Мисаїла у Вільні свідчить «Послання Мисаїла», місцем постання якого зазначено саме це місто. Про перебування в Новгородку знаємо з його грамоти (заповіту?) з наданням місцевому кафедральному собору Свв. Бориса та Гліба від 5 лютого 1480 р. (див.: Мікульскі Ю.М. Беларускія граматы 1460-1544 гг. са сховіщаў Вільні і Варшавы // Беларуская даўніна: Studia et fontes. - Вып.3. - Мінск, 2016. - С.142-143; Жалованная грамота митрополита Мисаила соборной церкви в Новогрудке 1480 г. // Там жа. - Вып.1. - Мінск, 2014. - С.144-145).

${ }_{63}$ Саме таку позицію див.: Ульяновський В. Митрополит Київський Спиридон... - С.86-88).

${ }^{64}$ В.Ульяновський убачає за підписом князя Михайла Олельковича на «Посланні Мисаїла» 1476 р. лише маневр, тоді як насправді Олельковичі начебто таємно підтримували Спиридона (пор.: Ульяновсъжий В. Митрополит Київський Спиридон... - С.20, 83, 88). Проте жодних історичних звісток, які могли б дати підстави для таких тлумачень, немає, тому видається доречнішим покладатися на наявні свідчення, інакше будь-яке історичне джерело можна трактувати в дусі «теорії змови», проглядаючи за ним якісь приховані мотиви та відчитуючи там що завгодно, навіть щось цілком протилежне тому, що сказано у самому джерелі.
} 
I2) На відсутність покровителів Спиридона як альтернативи Мисаїлу та Геронтію в межах Київської митрополії (і то як у Нижній, так і у Верхній іï частинах) указує також тривале перебування в Константинополі: його становище як митрополита було надто непевним. Адже якби за ним справді стояли певні впливові особи, то він поспішив би до своєї митрополії, щоб зміцнити власну позицію як єдиного предстоятеля (тим більше, що В.Ульяновський обстоює тезу про пізнє обрання Мисаїла, щойно після висвячення Спиридона) та захопити митрополичий престол, а не сидів би роками у Царгороді. Проте, не маючи достатньої підтримки ані в Литві (де не пізніше травня I473 р. митрополитом був обраний Мисаїл), ані на підмосковських теренах (де з кінця червня I473 р. митрополичий престол посів Геронтій), він, вочевидь, намагався заручитися тим більшою підтримкою з боку султана, патріарха та місцевого грецького духівництва, що справді вимагало тривалішого перебування для нав'язування і зміцнення контактів.

І3) При цьому заслуговує на увагу припущення В.Ульяновського, що «довіру султана Спиридон міг здобути спеціальною інформацією» ${ }^{65}$. Однак навряд чи відомості про поїздку митрополита Кафи (яка до I475 р. була генуезькою колонією) до Литви могли бути підставою для висвячення на київську кафедру. Радше такою інформацією була звістка Спиридона про паралельні контакти Мисаїла (за яким стояв Казимир IV) із папою, що не могло не викликати занепокоєння султана, для якого римський понтифік був загрозою через небезпеку скликання нового хрестового походу проти турків задля визволення Константинополя ${ }^{66}$. Особливо актуальною як надана інформація, так і кандидатура Спиридона виявилися з огляду на переговори щодо створення антитурецької коаліції, які саме в I473-I476 pp. дуже пожвавилися при дворі Казимира Ягеллончика ${ }^{67}$. Не дивно, що Мегмед II вирішив вплинути на патріарха, щоб посадити на митрополичий престол Києва «свого» ставленика. Контакти Мисаїла з папою були небезпечними і для патріарха ${ }^{68}$, котрий втрачав виняткове право на обсаджування Київської митрополії. Тож такий хід був вигідний і для очільника Константинопольського патріархату, адже після втрати впливу на Москву з ії митрополитами-розкольниками ${ }^{6}$ він не міг собі дозволити, щоб і єпархії в Польсько-Литовській державі вислизнули з-під його контролю. Тому якраз вістка

\footnotetext{
${ }_{65}$ Улъяновсъкий В. Митрополит Київський Спиридон... - С.74.

${ }_{66}^{6}$ Так, напр., папа Пій II (помер 1464 р.) робив активні кроки у цій справі (див.: Helmrath J. Pius II. und die Türken // Europa und die Türken in der Renaissance [Her. B.Guthmüller]. - Tübingen, 2000. - S.79-137).

${ }_{67}$ Одним із головних учасників цього процесу був молдавський воєвода Стефан III Мушат, який висловлював готовність стати васалом Казимира IV, просячи натомість військову допомогу в боротьбі проти турків. Інший активний учасник перський шах Узун Гасан - навіть пропонував віддати одну зі своїх дочок заміж за одного з синів Казимира, обіцяючи як посаг відвоювати Константинополь і всю Грецію та посадити там королевича правителем, якщо польсько-литовський володар долучиться зі своїми полками до його 300-тисячного війська у війні проти турків. Тема антитурецької коаліції в 1473-1476 рр. стала враз дуже актуальною при дворі Ягеллончика, як свідчив один із найпоінформованіших тогочасних польських літописців Я.Длугош (див.: Dtugosz J. Dzieje polskie... - S.566-567, 586-589, 591-595, 607-613). Тож мова про необхідність такої коаліції в «Посланні Мисаїла» цілком відповідала політичним реаліям тих років: «Тому-то повинен єси, всенайсвятіший отче, як найвищий пастир, про такі речі дбати й трудитися: про вівці стада Христового, щоб не розійшлися по горах і не були пожерті дикими вовками або злодіями й розбійниками [...] покрадені в їхні власні двори. Це ж мовимо про турків та про татар і про всіх інших поган. Бачачи розлад і непомірну поміж нами нелюбов, вони багато країв християнських посіли й у свій закон Магометів багатьох із них навернули. Уже-бо нині вони й біля нас самих близько, а що вчинили вони (з тими), що були близько, про них не знаємо - Бог один знає. Проти таких слід ворогувати спільно всьому родові християнському, проти ворогів хреста Христового й віри Христової» (див.: Заторський о. Н. «Послання Мисаїла до папи Сикста IV» 1476 року... - С.441-442).

${ }_{68}$ Припущення, що патріарх Рафаїл зважився на висвяту Спиридона саме через унійність Мисаїла висловлював, зокрема, А.Карташов (хибно постулюючи при цьому, що Спиридона висвячували лише для Литви) (див.: Картамёв А.В. Очерки по истории русской церкви. - Москва, 1993. - С.551).

69 Переконливі аргументи про невизнання московських митрополитів константинопольськими патріархами навів іще О.Шпаков (див.: Шпаков А.Я. Государство и церковь в их взаимных отношениях в Московском государстве от Флорентийской унии до учреждения патриаршества. - К., 1904).
} 
про одночасні відносини Мисаїла з папою могла стати тією краплею, що змусила як світську, так і церковну владу у Царгороді замість листа з благословенням Мисаїлові висвятити на його місце Спиридона ${ }^{70}$ (якщо мав місце не обман із підміною імені, як колись у випадку Мітяя, а, що ймовірніше, саме інтрига $)^{71}$.

14) Малоймовірним $є$ припущення, що за висвяченням Спиридона стояли якісь особи на підконтрольних Москві територіях, адже там чудово знали, що патріархи не визнавали поділу митрополії та поставлених за наказом московського князя митрополитів. Тому причин посилати кандидата, який у силу своїх свячень патріархом міг претендувати й на північноруські терени, у Москви явно не було. Остання обставина вельми важлива для розуміння мотивів ув'язнення Спиридона після його прибуття до Московії після 1482 р.: на противагу до невизнаних Константинополем «Ионы и бывшехъ по немъ» митрополитів, Спиридон, будучи висвяченим патріархом, мав набагато більше прав на митрополичий престол і ставився у Царгороді митрополитом для всієї території Київської митрополії, включаючи північні підмосковські терени.

На те, що Спиридона в Константинополі ставили на всю Київську митрополію, включно з підмосковськими єпархіями, указують, зокрема, його власні слова, зафіксовані як у Софійському, так і Львовському літописах, де безпрестольний митрополит передає через свого посланця до великого князя московського: «Много, рече, мощей отъ патриарха везохъ къ тебь» ${ }^{72}$. Якщо Спиридона ставили лише для Литви, то чому він віз мощі від патріарха саме для великого князя московського? Вочевидь для того, щоб задобрити його, аби той, прийнявши висвяченого в Константинополі митрополита також і для своєї території, визнав владу патріарха та закінчив період розколу. Хоча Типографський літопис повідомляє, що Спиридон «приіде изъ Царяграда в Литовьскоую землю» ${ }^{73}$, проте це була лише перша зупинка на його шляху, яка відповідала географії подорожі з Константинополя, а далі передбачалася поїздка до великого князя московського, про що свідчить наведений вище уривок зі словами невизнаного митрополита, що він віз для московського князя багато «мощей отъ патриарха».

Додатковим свідченням на користь того, що й Москва сприймала Спиридона як поставленого на всю територію Київської митрополії, включно $з$ північними єпархіями, котрі контролював великий князь московський, була практика, відома лише для підмосковських теренів і цілком незнана в єпархіях Польсько-Литовської держави відречення від Спиридона у чині поставлення єпископа ${ }^{74}$. Зокрема в «повольній»

\footnotetext{
70 В.УАьяновський цілком слушно зауважус: «ВАасна ж ініціатива султана і патріарха видасться досить сумнівною, принаймні менш достовірною» (Аив.: Ульяновський В. Митрополит Київський Спиридон... - С.75). Та у цьому і справа, що ініціатива була Спиридона, а обидва можновладці пристали на неї, побоюючись нового хрестового походу проти турків (у випадку султана) та втрати виняткового впливу на єпархії в Аитві й Польщі (у випадку патріарха).

71 Це Аозволяе по-новому поглянути й на слова Типографського Аітопису, що Спиридона поставили «повельніемъ Турскаго царя» (пор.: ПСРА. - Т.24. - С.195). У випадку, якщо Спиридона поставили замість Мисаїла, то ці слова означають не Аише, що його поставлено у захопленому турками Константинополі, а й те, що за висвятою стояв султан. Цю тезу обстоював, сереА інших, о. П.Біланюк, наводячи як мотивацію ААя такого вчинку спробу тиску Мегмеда ІІ на польсько-литовську церковну й політичну еліту. 3 огляду на перемовини про антитурецьку коаліцію при Аворі Казимира IV в 1473-1476 рр. така мотивація виглядас цілком правдоподібно (Аив.: Bilaniuk P.B.T. The Five-Hundredth Anniversary of the Letter of Misael... - P.134).

72 ПСРА. - Т.6. - С.233; Т.20. - Ч.1. - С.348.

73 Там же. - T.24. - С.195.

74 Те, наскільки історики були засліплені анахронічною (принаймні Аля 1470-х рр.) концепцісю окремих митовських і московських митрополитів, промовисто ілюструє біографія Спиридона, укладена А.Нікольським, який спершу

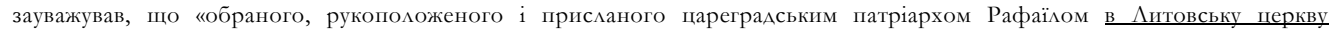
митрополита С(пиридона) король Казимир не прийняв». I тут же цитував присягу підмосковських кандидатів на єпископство з віАреченням віА Спиридона, з якої однозначно випливає, що ії уклаАачі сприймали Київську митрополію сАиною: «У Москві повірили, що він був поставлений по мзА $і$ у запобігання подібних випадків на майбутній час у саму присягу епископську внесено було такі слова: “отрицаюсь [...] посль Исидора и Григорія Болгарина и Спиридона, нарицаемаго Сатана [...] такожде и всьхъ тьхъ отрицаюсь, еже по немъ когда случится пріити на Кіевъ
} 
грамоті тверського єпископа Вассіана, виданій близько 6 грудня I477 р., читаємо: «А к митрополиту к Спиридону, нарицаемому Сатане, възыскавшаго в Цариграде поставлениа, во области безбожных турков от поганаго царя, или кто будеть иный митрополит поставлен от латыни или от турскаго области, не приступити мне к нему, ни соединениа ми с ним не имети никакова»75. Якби московська світська та церковна влада сприймали Київську митрополію остаточно поділеною, а Спиридона - як митрополита лише для Литви, його не розглядали б як загрозу для себе та не вимагали б у кандидата на єпископа відречення від нього ${ }^{76}$.

I саме тому московський правитель не міг залишити Спиридона на свободі після прибуття на підконтрольні йому терени, адже канонічні права на митрополичий престол були набагато вагомішими за права самовільно вибраних за наказом великого князя московського й не визнаних жодним авторитетом митрополитів. Власне в такому ключі слід розуміти Спиридонове представлення себе «митрополитомъ киевьскым Спиридономъ, всеа Р8сии архиепспмъ»77 у «Житії святих преподобних Зосими та Савватія Соловецьких», створеному ним уже на засланні, у Ферапонтовому мо-

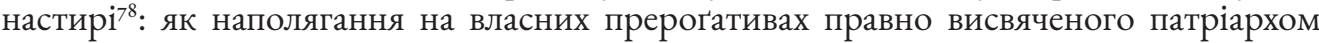
константинопольським митрополита супроти самозваних, поставлених за наказом світської влади Москви.

На користь висловлених вище припущень свідчить і момент утечі Спиридона з ув'язнення в Литві. В.Ульяновський датує ії кінцем I48I-го, а радше першою половиною 1482 р., напередодні захоплення і зруйнування татарами Києва ${ }^{79}$. При цьому він намагається довести, що від Спиридона перед цим вимагали зречення від митрополитства. Проте, посилаючись на маргінальну помітку в рукописі 762 головного зібрання Трійце-Сергієвої лаври (фонд 304/I Російської державної бібліотеки в Москві), дослідник помилково долучив коментар писця про Спиридона до зауваження про насильницьке усунення з престолу московським великим князем новгородського архієпископа Теофіла. Рукопис 762 оцифровано й викладено у Всесвітню мережу, тож ознайомлення з ним дозволяє зауважити, що згадка про Спиридона зроблена

отъ Рима латинскаго или отъ Царьграда турецкія державы”. Слова ці містилися ще в архієрейській присязі за митрополита московського Симона (1495-1511)» (див.: Никольский А. Спиридон, митрополит Киевский // Русский биографический словарь. - Т.19. - Санкт-Петербург, 1909. - С.259-260; пор.: Русская историческая библиотека. Т.6. - Санкт-Петербург, 1880. - Ст.451, прим.3). Навіщо єпископам Московської митрополії відрікатися від Спиридона, якщо він був присланий для окремої (за словами А.Нікольського) Київської (Литовської) митрополії (чи інших митрополитів для Києва, поставлених не в Москві), історик так і не пояснив, ба навіть не зауважив внутрішньої суперечності наведених тверджень. Непереконливим є припущення Р.Дмитрієвої, що «Москва побоювалася його більш за все як представника тверської політичної сили» (див.: Дмитриева Р.П. Спиридон-Савва... - С.408). Якби це було так, то необхідности відрікатися від Спиридона після підкорення Твері 1485 р. більше не було б, натомість сама дослідниця вказує на відречення від нього ще за часів митрополита Симона (1495-1511) (див.: Там же). Тому найочевиднішою причиною відречення від Спиридона був саме факт його поставлення патріархом, що робило його права на митрополичий престол набагато вагомішими за права поставлених у Москві митрополитів-самозванців.

${ }_{75}$ Русский феодальный архив XIV - первой трети XVI вв. - Ч.3. - С.690. Тут, знову-таки, явно простежується сприйняття Київської митрополії як єдиної, навіть попри ії тимчасовий (як тоді вважали) поділ, адже мова у цьому відреченні просто про митрополита, поставленого чи то в Римі, чи то у Царгороді, себто митрополита київського, без характерного для пізніших істориків означення «литовського» чи «московського».

76 Тому хибним є тлумачення Н.Сініциної, що Спиридон висував претензії також на Московську митрополію. Жодних таких зазіхань не могло бути вже тому, що подібної митрополії на той час просто не існувало, натомість у свідомості всіх учасників подій далі існувала Київська, як свідчить цитований самою ж авторкою текст присяжної грамоти тверського єпископа Вассіана (пор.: Синищына Н.В. Третий Рим... - С.113-114). Зрештою, Спиридон називав себе митрополитом київським, тому його претензії на підмосковські єпархії могли висуватися лише в рамках його повноважень київського митрополита, для якого Київська митрополія включала у себе як литовські, так і московські території.

7 Великие Минеи Четии, собранные всероссийским митрополитом Макарием. - Апрель, тетрадь вторая. - Дни 8-21. - Москва, 1912. - С.551.

${ }_{78}$ Див.: Дмитриева Р.П. Житие Зосимы и Савватия Соловецких в редакции Спиридона-Саввы // Книжные центры Древней Руси XI-XVI вв. - Санкт-Петербург, 1991. - С.222.

79 Ульяновський В. Митрополит Київський Спиридон... - С.257-258. 
писцем не в контексті примушування Іваном III Васильовичем новгородського архіпастиря зректися престолу, а щодо зовсім іншої події, а саме «стояння на Угрі». Так, безпосередньо перед заміткою про Спиридона мовиться: «црь на оу/грђ стаял / да и пабъ/жалъ нае/мврия ігґ (де під «царем» мається на увазі татарський володар Ахмат, адже московського правителя називали великим князем, як свідчать інші маргіналії цього рукопису). Тобто «цар (татарський) стояв на Угрі та й утік». I тут же під цим написом іде згадка Спиридона: «тогдаж и спиридонъ» ${ }^{80}$. Тобто, якщо слідувати за матрицею тлумачення В.Ульяновського, коли одна помітка змістовно прив'язується до іншої, то від Спиридона не зречення від митрополитства вимагали, а тоді він «пабъжалъ». Себто втечу його з литовського ув'язнення слід датувати саме кінцем 1480 р. Більше того, перед записом про «стояння на Угрі» також немає запису про зречення Теофіла з новгородської кафедри, як подає дослідник ${ }^{81}$, а йдеться про його ув'язнення в Москві: «влдк8 новго/родцказ на мо/скву приве/зли Өеофїла». А оскільки це, як свідчить сам автор, відбулося 1480 p. ${ }^{82}$, то замітка про Спиридона належить до того ж I480 p., що й обидві інші маргінальні помітки на арк. 25і зв. Натомість про насильницьке усунення Теофіла з престолу архієпископа Новгорода розповідає запис наступного арк. 252, де описуються події I48I-I482 pp., але й там це не перша маргіналія, тому прив'язувати іï до мови про Спиридона немає жодних підстав ${ }^{83}$. Отже оповідь про втечу Спиридона стосується кінця I480 р., приблизно того ж часу, коли відбулося «стояння на Угрі». Однак В.Ульяновський, усупереч свідченню збірника 762, намагається прив'язати замітку про втечу Спиридона саме до примусового зречення новгородського архієпископа Теофіла ${ }^{84}$, хоч ця подія відділена від звістки про Спиридона двома іншими нотатками, тоді як насправді втеча, за свідченням маргіналій збірника 762, мала місце наприкінці I480 р. При цьому звістку про втечу Спиридона слід трактувати з такою ж обережністю, як і про втечу татарського царя з Угри: опис розходження військ московського князя Івана III Васильовича та хана Ахмата терміном «пабъжалъ» щодо останнього відображає радше суб'єктивну оцінку, ніж реальний стан справ. Тому мова про Спиридона в тому ж контексті швидше за все також відображає скоріше чутки, які дійшли до автора маргіналій, та його власні уявлення. Цілком певним є лише те, що наприкінці 1480 р. Спиридон уже не був ув'язненим і змінив місце свого перебування - факт, який міг викликати поголос про його втечу та

\footnotetext{
${ }^{80}$ Див.: Рук. 762 (Сборник). - XV в. - Л.251 об. (Российская государственная библиотека (Москва). Научноисследовательский отдел рукописей. - Ф.304.I) [Електронний ресурс]: https://lib-fond.ru/lib-rgb/304-i/f-304i762/\#image-252

${ }^{81}$ Пор.: Ульяновський В. Митрополит Київський Спиридон... - С.45.

82 Див.: Ульяновський В. Митрополит Київський Спиридон... - С. 46. При цьому впадає у вічі, що всі маргінальні помітки рукопису 762 зроблені у хронологічному порядку: так, на арк. 250 зв. ідеться про мирну поїздку великого князя московського Івана III Васильовича до Новгорода: «княз велїкї/ в новьгород/ мироิм ходил/ тобто мова про в”їзд до Новгорода 23 жовтня 1475 р. (у записі датовану 22 жовтня). На наступному арк. 251 указано вже про взяття Новгорода, яке відбулося після московсько-новгородської війни 1477-1478 рр.: «кнзь велїки/ взя л велики/ нобгород за щи/том̄. Тобто бачимо, що маргінальні замітки розташовано за хронологією подій (до речі, з огляду на велике зацікавлення справами Новгорода, у затертому записі про постриг на арк. 252 могло йтися про постриг Марфи-посадниці.) Маргінальні записи збірника завершуються на арк. 254 звісткою про смерть великого князя Івана Івановича (вочевидь ідеться про Івана Івановича Молодого, який помер 1490 р.), а завершення загального опису «круга» на арк. 254 зв. свідчить, швидше за все, про очікування близького кінця світу на 1492 р., адже там читаємо: «сеже посльдне/е льто седми тысоущь», а тоді: «кшнець. седми тысоущаิм. трце стая слава тобъ».

${ }_{83}$ Так, перша маргіналія на арк. 252 стосується вже 1481 р.: «преставися/ кеззь андрђи/ иоуля є». Під цим «князем Андрієм» мається на увазі, без сумніву, Андрій Васильович Менший, який помер у липні 1481 р. І лише після цього

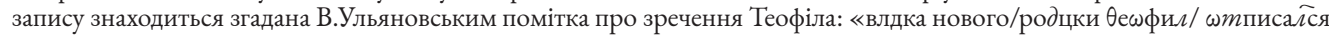
св/єБ архиєпспьї». Відтак іде затертий запис про постриг (Марфи-посадниці?). Тоді на лівому маргінесі того ж арк. 252 внизу йде вертикально запис про взяття Києва Менглі Гіреєм 1 вересня 1482 р.: «сеп а києвъ мингирђи взял (тоді внизу під головним текстом горизонтально продовжено - Н.3.) и монастырь печерьски прчстыя бца».

${ }_{84}$ Ульяновський В. Митрополит Київський Спиридон... - С.45-47.
} 
дати підстави авторові маргіналій збірника 762 тлумачити цю подію в такому ж ключі, як і «втечу» хана Ахмата.

Таке раннє датування звільнення Спиридона з ув'язнення в Литві г480-м роком відповідає хронології та логіці подій, адже саме на першу його половину припали смерть Мисаїла й обрання наступного митрополита Симеона, конкурентом якого світська влада Литви з тих чи інших причин Спиридона вже не розглядала. Тому останньому цілком могли як замінити в'язницю на заслання, так і просто дати можливість утекти, бажаючи позбутися висвяченого в Константинополі Спиридона перед тим, як просити в патріарха благословення для вибраного на митрополію Симеона.

Наступна звістка, яку ми маємо щодо Спиридона, стосується I482 р., коли він почав перемовини через «пана з Литви» з московським великим князем Іваном III Васильовичем ${ }^{85}$. Тут цілком доречно постає питання про місце його перебування між I480 та I482 рр. Можливими видаються два припущення, залежно від того, що насправді відбулося зі Спиридоном у г48о р. Якщо мала місце зміна ув’язнення на заслання, то слушним виглядає припустити, що віддалене м. Пуня цілком могло бути не місцем ув'язнення Спиридона до І48о р., а місцем його заслання після обрання нового митрополита Симеона, де безпрестольний ставленик Царгорода втішався певною свободою. На користь такого припущення свідчить факт створення ним тут «Слова на Зішестя Святого Духа» та, імовірно, «Викладу про православну віру» ${ }^{86}$. Це вказує не лише на доступ Спиридона до бібліотеки, а й на можливість писати власні твори, що ледве чи було б йому дозволено в той час, коли його розглядали як конкурента Мисаїла і тримали в ув'язненні, себто до І48о р.

У випадку ж, якщо Спиридонові I48о р. дали втекти, то єдиним імовірним напрямком такої втечі могли бути північноруські землі, що було вельми вигідно як для світських, так і для церковних еліт Польсько-Литовської держави, оскільки перекладало проблему наявності законно висвяченого митрополита з повноваженнями на всю територію Київської митрополії на голову сусіда, якому доти так і не вдалося добитися визнання своїх митрополитів у Константинополі. Проте той факт, що I482 p. на перемовини до Івана III Васильовича прибув «пан із Литви», а не з якихось інших земель, свідчить радше на користь першого припущення. На користь того ж таки припущення, що І480 р. мала місце зміна суворого ув'язнення на лагідніше заслання в Пуні, говорить і контекст звістки літопису, з якої випливає, що Спиридон уже мав достатньо свободи, щоб могти послати певного пана до великого князя московського, але на волі ще не перебував, адже як за словами посланця, так і за відповіддю московського правителя проглядає тема війни за остаточне звільнення Спиридона ${ }^{87}$.

У перемовинах із Москвою I482 р. знову проявилася «рђзвость» Спиридона, адже саме на той рік припала сварка Івана III Васильовича з тодішнім митрополитом

\footnotetext{
${ }^{85}$ Опис цього посольства знаходиться у 2-му Софійському літописі: «Того же льта пріБздилъ панъ изъ Литвы, “отъ митрополіи же здђ чернець бывалъ, его же Сотоною зовутъ за рђзвость его, и шедъ въ Царьградъ ста въ митрополиты на Русь, и приҺхавъ Литву, король же ятъ его и посади в заточеніи”, и сказа отъ него князю великому: “яко много, рече, мощей отъ патріарха везохъ къ тебъ, король же все поима къ себъ”; князь же велики держа долго пана того и отпусти, рекъ: “не подымати рати, ни воеватися съ королемъ про се”» (див.: ПСРЛ. - Т.6. - С.233).

${ }^{86}$ Стосовно місця постання обох творів певність є лише щодо першого, в якому це прямо зазначено, тоді як із приводу «Викладу...» думки розділилися: одні дослідники вважають, що його написано ще в Литві, тоді як інші схиляються до думки, що це був Ферапонтів монастир, куди Спиридона запроторили після прибуття до Московії (див.: Ульяновський В. Митрополит Київський Спиридон... - С.115-120; критику аргументів В.Ульяновського див.: Алексеев А.И. «Спиридон рекомый, Савва глаголемый» (заметки о сочинения Киевского митрополита Спиридона) // Древняя Русь: Вопросы медиевистики. - Вып.3(41). - Москва, 2010. - С.5-16).

87 Хоча синтаксис дозволяє віднести мову про війну також до мощів (пор. прим. 85), проте навряд чи таке тлумачення правильне, адже серйозно пропонувати відібрані мощі як привід для війни такий вправний інтриган як Спиридон навряд чи міг.
} 
з осідком у Москві Геронтієм ${ }^{88}$, яку безпрестольний ієрарх вочевидь намагався використати задля просування власних інтересів. За такою його активністю простежується певний типовий для нього спосіб дій, який також свідчить на користь висловленої раніше гіпотези про те, що у Царгороді Спиридон добився власного поставлення замість патріаршого благословення для обраного митрополитом Мисаїла, використавши для цього тамтешню світську владу. У перемовинах 1482 р. він намагався повторити успішно апробовану в Константинополі модель: через контакти зі світським правителем добитися митрополичого престолу для себе та відтіснити наявного конкурента - цього разу Геронтія, до речі, поставленого на митрополію того ж самого, що й Мисаїл, 1473 р., себто також раніше за Спиридона.

\section{REFERENCES}

1. Alekseev, A.I. (2010). "Spiridon rekomyj, Savva glagolemyj" (zametki o sochineniyakh Kievskogo mitropolita Spiridona). Drevnyaya Rus: Voprosy medievistiki, 3(41), 5-16. [in Russian].

2. Bilaniuk, P.B.T. (1992). The Five-Hundredth Anniversary of the Letter of Misael, Metropolitan-Elect of Kiev, to Pope Sixtus IV (1476-1976). Studies in Eastern Christianity, 131-141.

3. Bulgakov, Makarij. (1994-1996). Istoriya Russkoj Tserkvi (12 vols., repr. ed.). Moskva. [in Russian].

4. Dmitrieva, R.P. (1989). Spiridon-Savva, kievskij mitropolit. Slovar knizhnikov i knizhnosti Drevnej Rusi, 2, 2, 408-411. Leningrad. [in Russian].

5. Dmitrieva, R.P. (1991). Zhitie Zosimy i Savvatiya solovetskikh v redaktsii Spiridona-Savvy. Knizhnye tsentry Drevnej Rusi XIXVI vv., 220-282. [in Russian].

6. Florya, B.N. (1999). Popytka osushchestvleniya tserkovnoj unii v Velikom knyazhestve Litovskom v poslednej chetverti XV nachale XVI v. Slavyane i ikh sosedi, 7, 40-81. Moskva. [in Russian].

7. Florya, B.N. (2007). Issledovaniya po istorii tserkvi: Drevnerusskoe i slavyanskoe srednevekove. Moskva. [in Russian].

8. Gil, A. \& Skoczylas, I. (2013). Przed wielkim podziatem: prawostawna metropolia kijowska do 1458 roku. Lublin: Instytut Europy Środkowo-Wschodniej; Lwów: Ukraiński Uniwersytet Katolicki. [in Polish].

9. Gil, A. \& Skoczylas, I. (2014). Kościoty Wschodnie w państwie polsko-litewskim w procesie przemian i adaptacji: Metropolia Kijowska w latach 1458-1795. Lublin: Instytut Europy Środkowo-Wschodniej; Lwów: Ukraiński Uniwersytet Katolicki. [in Polish].

10. Gudziak, B. (2000). Kryza i reforma: Kyivska mytropoliia, Tsarhorodskyi patriarkhat i beneza Beresteiskoi unii. Lviv. [in Ukrainian].

11. Halecki, O. (1958). From Florence to Brest (1439-1596). Rome; New York: Sacrum Poloniae Millenium.

12. Helmrath, J. (2000). Pius II. und die Türken. Europa und die Türken in der Renaissance. Tübingen. [in German].

13. Hrushevskyi, M. (1991-1998). Istoriia Ukrainy-Rusy (11 vols., repr. ed.). Kyiv. [in Ukrainian].

14. Kartashev, A.V. (1993). Ocherki po istorii Russkoj tserkvi. Moskva. [in Russian].

15. Lure, V.M. (2009). Russkoe pravoslavie mezhdu Kievom i Moskvoj. Moskva. [in Russian].

16. Luzhnytskyi, H. (1954). Ukrainska tserkva mizh Skhodom i Zakhodom. Filadelfiia. [in Ukrainian].

17. Mikulski, Yu.M. (2014). Zhalovannaya gramota mitropolita Misaila sobornoj tserkvi v Novogrudke 1480 g. Belaruskaia daunina: Studia et fontes, 1, 144-146. Minsk. [in Russian].

18. Mikulski, Yu.M. (2016). Belaruskiia hramaty 1460-1544 hh. sa skhovishchau Vilni i Varshavy. Belaruskaia daunina: Studia et fontes, 3, 131-184. Minsk. [in Belarusian].

19. Pliguzov, A.I. (1992). O titule „mitropolit kievskij i vseya Rusi”. Russkij feodalnyj arkhiv XIV-pervoj treti XVI vv., 5, $1034-1042$. Moskva. [in Russian].

20. Prokhorov, G.M. (1978). Povest o Mityae: Rus i Vizantiya vepokbu Kulikovskoj bitvy. Leningrad. [in Russian].

21. Rusyna, O. (2017). Polityko-konfesiini oriientyry pravoslavnykh kantseliarystiv rubezhu XV-XVI st. Ukrainskyi istorychnyi zhurnal, 5, 4-23. [in Ukrainian].

22. Sinitsyna, N.V. (1998). Tretij Rim: Istoki i evolyutsiya russkoj srednevekovoj kontsepcii. Moskva. [in Russian].

23. Skochylias, I. (2011). Halytska mytropoliia XIV - pershoi polovyny XV st.: osoblyvosti eklezialnoho, pravovoho ta suspilnoho statusu. Kniazha doba: istoria i kultura, 4, 246-279. [in Ukrainian].

24. Tsukerman, K. (2017). Iz rannoi istorii Lytovskoi mytropolii. Rutbenica, XIV, 185-197. [in Ukrainian].

25. Turilov, A.A. (1999). Zabytoe sochinenie mitropolita Savvy-Spiridona litovskogo perioda ego tvorchestva. Slavyane $i$ ikh sosedi, 7. Moskva. [in Russian].

26. Ulianovskyi, V. (2004). Mytropolyt Kyivskyi Spyrydon: Obraz kriz epokbu, epokba kriz obraz. Kyiv: Lybid. [in Ukrainian].

27. Untergehrer, W. (2012). Die päpstlichen nuntii und legati im Reich (1447-1484): Zu Personal und Organisation des kurialen Gesandtenwesens. München. [in German].

28. Vavryk, M. (1963). Florentiiski uniini tradytsii v Kyivskii mytropolii 1450-1460 rr. Analecta OSBM, 4(10), (3-4), 329-362. [in Ukrainian].

29. Zatorskyi, N. (2017). Posolstvo do papy Syksta IV z poslanniam Mysaila u svitli deiakykh dokumentiv Vatykanskoho taiemnoho arkhivu. Mizhnarodni zviazky Ukrainy: naukovi posbuky i znakbidky, 26, 11-30. [in Ukrainian].

30. Zatorskyi, N. (2019). „Poslannia Mysaila do papy Syksta IV” 1476 roku: rekonstruktsiia arkhetypu, 2nd ed. Lviv: Vyd-vo UKU. [in Ukrainian].

\footnotetext{
${ }_{88}$ Слід зауважити, що тут на руку московському монархові грала не лише сварка з Геронтієм і нагода його провчити, погрожуючи прийняти та визнати Спиридона. Думка використати висвяченого в Константинополі ієрарха для подолання неканонічності своєї церкви й одночасного оголошення претензій на єпархії в Польсько-Литовській державі могла видаватися йому вельми спокусливою - вочевидь саме на це Спиридон і розраховував.
} 


\author{
Nazar ZATORSKYI \\ Candidate of Historical Sciences (Ph. D. in History), \\ Doctoral Student in Theology, \\ University of Fribourg \\ (Fribourg, Switzerland), nazar.zatorsky@unifr.ch \\ ORCID: https://orcid.org/oooo-00o2-II8I-0207
}

\title{
The Consecration of Metropolitan Spyridon in the Context of the Epistle of Misael 1476
}

\begin{abstract}
The paper aims at shedding a new light on the consecration of the monk Spyridon the Metropolitan of Kyiv in the mid-1470s in Constantinople, considering the situation in the Kyiv metropolitanate after the Florentine Union (1439) with a due regard to the witness of the Epistle of Misael (1476) concerning the confessional attitude and actions of the Ruthenian and Lithuanian secular and spiritual elite. On the basis of historiographical and source analysis the author discovers new possible readings of Spyridon the Satan's biographical data and proposes a new interpretation of his mission to Constantinople and identification of patrons behind him. The author also adjusted the date of Spyridon's escape or release from imprisonment in Lithuania. The author considers the dating of the division of Kyiv metropolitanate by 1448 or 1458 ungrounded. The documents and behavior of all interested parties indicate that even in the late 1460 s they regarded it as a unit and tried to control its entire territory. Furthermore, the actions of the Polish-Lithuanian monarch Casimir IV with regard to Metropolitan Hryhorii Bolharynovych testify to his attempt to introduce a new modus vivendi for the Orthodox Ruthenians by providing them with a dual jurisdiction: both of Rome and of Constantinople. The election of Misael for the metropolitan see of Kyiv in early 1473 was made primarily in view of the prospects for his recognition in the territories controlled by Moscow. Some passages of the Epistle of Misael of 1476 testify to the continuing policy of double communion and its support by the Ruthenian secular and spiritual elite. This approach reveals not only the reason for Spyridon's embassy in Constantinople, but also the importance of chronicles' information on cunning nature of the envoy and acquisition of the Metrpolitan dignity by bribery.
\end{abstract}

Keywords: Spyridon the Satan, Misael, Epistle of Misael, Union of Florentine, Kyivan Metropolitanate. 